\title{
ANALISA PENGARUH INFLASI \& GDP (GROSS DOMESTIC PRODUCT) TERHADAP ROAA (RETURN ON AVERAGE ASSETS) PADA 10 BANK DENGAN KATEGORI ASET TERBESAR DI INDONESIA PERIODE 2005-2008
}

\section{Arif Prawira dan Arnold Japutra}

\author{
E-mail: arif_wie@yahoo.com dan arn_gun@yahoo.com
}

\section{Penulis}

Arif Prawira adalah mahasiswa jurusan Manajemen di Universitas Bunda Mulia dengan bidang konsentrasi manajemen keuangan

Arnold Japutra adalah dosen tetap di Universitas Bunda Mulia.

\section{Abstract}

The background of this research is the phenomenon of global crisis began with Subprime Mortgage in America which make lots of company in finance get loss and a lot of them must be closed because of bankruptcy. The purpose of this research is to know the implication of macroeconomic especially inflation and GDP (Gross domestic Product) to ROAA (Return on Average Assets) in banking. The subject of this research is the ten biggest banks in category of asset in Indonesia. The object of this research is financial statements of the ten biggest banks in category of asset in Indonesia, GDP Indonesia and inflation in research's period. The result of this research are with level of confidence 95\%, inflation has not significant impact to ROAA while GDP was controlled and GDP has not significant impact to ROAA while inflation was controlled.

\section{Key Words}

ROAA, Inflation, GDP 


\section{PENDAHULUAN}

Fenomena yang terjadi baru-baru ini dan secara langsung mempengaruhi ekonomi di dunia adalah krisis global. Krisis global berawal dari krisis yang terjadi di Amerika karena adanya kasus Subprime Mortgage. Hal ini terjadi karena adanya kebijakan dari pemerintah setempat yang memberi kelonggaran dalam pemberian kredit dibidang properti. Sehingga masyarakat yang memiliki penghasilan yang kecilpun dapat membeli rumah dengan fasilitas kredit yang ada. Tanpa disadari ternyata menimbulkan dampak ketidakmampuan masyarakat yang berpenghasilan rendah untuk membayar kredit yang telah diambil tersebut. Kredit macet tersebut menyebabkan bank-bank yang telah memberikan kredit mengalami hambatan dalam penerimaan dan juga harus memenuhi kewajiban dari bank itu sendiri.

Salah satu penyebab bank harus ditutup adalah pengelolaan aset yang kurang baik. Aset merupakan sesuatu yang dimiliki perusahaan yang dapat diuangkan untuk memenuhi kewajiban dari perusahaan tersebut. Pengelolaan aset yang baik oleh bank akan mencerminkan kinerja bank itu sendiri dengan melihat salah satu rasio keuangan (rasio profitabilitas) yaitu ROA (Return On Assets).

Dalam melakukan kegiatan usahanya, bank tentunya harus mendapat kepercayaan dari masyarakat yang akan menyimpan dananya. Hal ini memiliki keterkaitan antara aset dari bank yang dimiliki dan pemenuhan kewajiban dari bank itu sendiri. ROA yang tinggi mencerminkan kemampuan menghasilkan laba yang baik dengan menggunakan aktiva yang dimiliki. Namun untuk menghasilkan laba atas sejumlah modal yang telah diinvestasikan, tentunya ada pengaruh dari faktorfaktor di luar bank itu sendiri yaitu faktor-faktor eksternal. Faktor-faktor ekonomi makro seperti GDP dan inflasi secara tidak langsung ikut mempengaruhi aset dari bank.

Penelitian yang dilakukan oleh Kyriaki Kosmidou tahun 2008 terhadap 23 bank di Yunani adalah mengukur kinerja bank-bank Yunani selama periode tahun 1990-2002. Dari penelitian tersebut, diambil kesimpulan bahwa pertumbuhan dari 
GDP (Gross Domestic product) berpengaruh signifikan dan positif terhadap ROAA. Sedangkan inflasi berpengaruh signifikan dan negatif terhadap ROAA. Hasil penelitian Kyriaki Kosmidou (2008) ini juga menemukan bahwa pertumbuhan money supply tidak berpengaruh signifikan terhadap profit, dimana rasio aset bank pada GDP, cadangan kapitalisasi pasar pada aset bank dan konsentrasi semuanya secara statistik berpengaruh signifikan dan negatif terhadap ROAA.

Berawal dari latar belakang permasalahan yang ada dan ketertarikan penulis pada penelitian Kyriaki Kosmidou (2008), maka penulis tertarik untuk melakukan penelitian mengenai pengaruh dari GDP (Gross Domestic Product) dan inflasi pada 10 bank dengan aset kategori terbesar di Indonesia periode 2005-2008. Alasan pemilihan 10 bank dan periode 2005-2008 tersebut adalah berdasarkan pertimbangan penulis pada konsistensi dari 10 bank tersebut dimana dari tahun 2005-2008 selalu menempati peringkat 10 besar dalam daftar perbankan dengan kategori aset terbesar di Indonesia.

\section{Tinjauan Pustaka}

Makroekonomi merupakan cabang dari ilmu ekonomi yang memiliki lingkup yang lebih luas mencakup kebijakan pemerintah setempat, hubungan dengan pihak luar negeri, tingkat suku bunga, tingkat inflasi serta besarnya investasi yang ada.

Selain itu, di dalam bukunya (Arnold 2008) menjelaskan mengenai makro ekonomi sebagai berikut: "macroeconomis is the branch of economics that deals with human behavior and choices as they relate to an entire economy."

Beberapa permasalahan yang muncul dalam ekonomi makro (Arnold 2008) adalah:

1. Tingkat inflasi yang tinggi

Tingkat inflasi yang tinggi menyebabkan masyarakat menjadi kesulitan dalam memenuhi kebutuhan hidupnya karena harga dari barang dan jasa yang meningkat diatas harga rata-rata yang berlaku. 
2. Tingkat pengangguran yang tinggi

Tingkat pengangguran yang tinggi mencerminkan bahwa lapangan kerja yang tersedia tidak cukup untuk menampung jumlah tenaga kerja produktif yang ada.

3. Tingkat suku bunga yang tinggi

Tingkat suku bunga yang tinggi membuat masyarakat menjadi kesulitan dalam mengajukan pinjaman

4. Pertumbuhan ekonomi yang rendah

Pertumbuhan ekonomi yang rendah menunjukkan secara kesuluruhan pergerakan ekonomi suatu negara berjalan lambat.

GDP (Gross Domestic Product) atau produk domestik bruto merupakan seluruh jumlah barang dan jasa yang dihasilkan oleh suatu negara dalam satu periode tahun berjalan. GDP dapat juga diartikan sebagai jumlah pengeluaran dari konsumsi masyarakat, investasi dari pihak swasta, pengeluaran belanja pemerintah, total ekspor dan total impor, GDP dapat didefinisikan sebagai berikut (McConnell dan Brue 2008):

"GDP is the total market value of all final goods and services produced in a given year. GDP includes all goods and services produced by either citizen-supplied or foreign-supplied resources employed within the country."

Sedangkan definisi lain dari GDP sebagai berikut (Parkin 2008): “GDP is the market value of all final goods and services produced within a country in a given time period."

Inflasi ialah (Williamson 2008) "the rate of change in the average level of prices. The average level of prices is reffered to as price level.". (McConnell dan Brue 2008,) juga mengatakan bahwa "Inflation is a rise in the general level of prices." 
Inflasi merupakan suatu perubahan dimana terjadi peningkatan harga barang atau jasa dari rata-rata harga sebelumnya yang berlaku. Dengan peningkatan harga barang dan jasa tersebut menyebabkan daya beli masyarakat menjadi rendah karena nilai dari uang menjadi semakin kecil. Sehingga setiap rupiah dari pendapatan yang diterima hanya dapat memperoleh barang dan jasa yang lebih sedikit dari sebelumnya.

Bila dikaitkan dengan GDP dan tingkat harga, ada dua faktor yang menyebabkan terjadinya inflasi (Parkin 2008) yaitu:

\section{Demand-Pull Inflation}

Keadaan ini menggambarkan bahwa tingkat harga dan GDP berada pada satu keseimbangan tertentu. Apabila terjadi kenaikan jumlah permintaan, harga cenderung bergerak meningkat. Hal ini ikut meningkatkan nilai GDP karena jumlah kuantitas pemintaan yang meningkat sehingga menyebabkan kurva aggregate demand bergerak ke kanan.

\section{Cost-Push Inflation}

Peningkatan biaya bisa terjadi pada nilai bahan dasar yang digunakan untuk kegiatan produksi. Hal ini membuat produksi menjadi berkurang dan menyebabkan kelangkaan di pasar. Barang atau jasa yang langka menyebabkan harga menjadi meningkat. Namun tidak diikuti oleh jumlah kuantitas yang menurun karena kelangkaan sehingga nilai GDP menjadi turun dan menyebabkan kurva aggregate supply bergerak ke kiri.

ROA atau return on asset merupakan salah satu rasio profitabilitas. ROA merupakan tingkat pengembalian atas aktiva. (Van Horne dan Wachowicz, JR. 2005) mengemukakan bahwa rasio ini mengukur efektivitas keseluruhan dalam menghasilkan laba melalui aktiva yang tersedia, atau daya untuk menghasilkan laba dari modal yang diinvestasikan. Sehingga melalui return on assets perusahaan dapat mengetahui seberapa besar laba yang mampu dihasilkan dengan jumlah aktiva yang dimilikinya. (Ross et al. 2008) mengemukakan bahwa "return on assets is a measure 
of profit per dollar of assets." Untuk mencari nilai ROA ini, kita dapat menggunakan rumus yaitu dengan mengalikan antara profit margin dengan total asset turnover.

$\begin{array}{ccc}\text { Return on assets }=\begin{array}{c}\text { Profit margin } \\ \frac{\text { Net income }}{\text { Sales }}\end{array} & X & \text { Total asset turnover }\end{array}$

Seperti yang kita ketahui, GDP (Gross Domestic Product) merupakan salah satu indikator ekonomi makro dalam menilai ekonomi negara. Total barang dan jasa yang dihasilkan dalam satu periode waktu tertentu ini ikut memberikan kontribusi dalam pertumbuhan ekonomi suatu negara. Pertumbuhan GDP memberikan indikasi terhadap kondisi ekonomi makro.

Penelitian lain (Kyriaki Kosmidou 2008) menyebutkan bahwa pertumbuhan GDP menggambarkan akibat dari adanya hubungan antara permintaan dan penawaran serta pinjaman dan simpanan. Terdapat pengaruh yang positif antara pertumbuhan GDP dengan performa bank yang ada.

Inflasi merupakan kondisi dimana secara tidak langsung mempengaruhi kenaikan harga barang dan jasa secara keseluruhan. Peningkatan inflasi dari satu periode ke periode berikut mencerminkan seberapa tinggi tingkat kenaikan harga yang terjadi. Inflasi secara langsung berpengaruh terhadap peningkatan upah tenaga kerja, secara tidak langsung berpengaruh terhadap tingkat suku bunga dan nilai aset dalam profitabilitas bank.

Penyesuaian tingkat suku bunga yang cepat akan memberikan total penerimaan bank yang meningkat lebih cepat dibanding biaya sehingga memberi dampak positif terhadap profitabilitas bank. Namun, bank mungkin juga lambat dalam menyesuaikan tingkat suku bunganya sehingga biaya yang meningkat lebih cepat daripada penerimaan bank merupakan konsekuensi dan pengaruh negatif terhadap profitabilitas bank. 


\section{Tujuan dan Manfaat Penelitian}

Tujuan dari penelitian yang dilakukan oleh penulis ini adalah :

1. Mengetahui apakah terdapat pengaruh yang negatif dan signifikan inflasi terhadap ROAA (Return on Average Assets) dari 10 (sepuluh) bank dengan kategori aset terbesar di Indonesia.

2. Mengetahui apakah terdapat pengaruh yang positif dan signifikan GDP (Gross Domestic Product) terhadap ROAA (Return on Average Assets) dari 10 (sepuluh) bank dengan kategori aset terbesar di Indonesia.

Manfaat dari penelitian yang dilakukan oleh penulis dalam penelitian ini adalah :

\section{Perusahaan}

Sebagai bahan referensi bagi pihak bank khususnya bank yang dibahas dalam penelitian ini maupun bank lainnya di luar bank yang dibahas dalam menilai pengaruh dari lingkungan eksternal perusahaan khususnya tingkat inflasi dan GDP terhadap pengelolaan terhadap aset yang dimiliki perusahaan berdasarkan hasil temuan yang terdapat dalam penelitian ini.

\section{Peneliti Selanjutnya}

Sebagai bahan referensi bagi peneliti selanjutnya yang akan melakukan penelitian yang berkaitan dengan penelitian ini.

\section{Penulis}

Sebagai bahan pengetahuan bagi penulis dalam menganalisa pengaruh dari faktor ekonomi makro khususnya inflasi dan GDP (Gross Domestic Product) terhadap ROAA (Return on Average Assets). 


\section{METODOLOGI PENELITIAN}

Jenis penelitian yang digunakan dalam penulisan penelitian ini adalah penelitian deskriptif yang bersifat kausal komparatif. Penelitian deskriptif merupakan penelitian yang berusaha untuk menuturkan pemecahan masalah yang ada sekarang berdasarkan data-data, juga menyajikan data, menganalisis dan menginterpretasikan. Bersifat komparatif yaitu bertujuan untuk menyelidiki kemungkinan sebab-akibat yang ada, mencari kembali fakta yang mungkin menjadi penyebab melalui data tertentu. Data yang digunakan oleh penulis dalam penelitian ini adalah data sekunder.

Dalam pengumpulan data, teknik pengumpulan data yang digunakan oleh penulis dalam penelitian ini adalah sebagai berikut:

- Observasi

Penulis melakukan observasi ke Bank Indonesia untuk mengumpulkan data laporan keuangan yang diperlukan dalam penulisan penelitian ini.

- Studi pustaka

Penulis juga melakukan studi pustaka dengan membaca literatur, buku bacaan, dan koran yang berkaitan dengan penelitian yang dilakukan.

Populasi dalam penulisan penelitian ini adalah 10 (sepuluh) bank dengan kategori aset terbesar di Indonesia berdasarkan data dari Bank Indonesia. Penulis tidak melakukan penarikan sampel dalam penelitian ini karena langsung meneliti 10 (sepuluh) bank tersebut yang merupakan populasi dari penelitian ini.

Berikut adalah tabel yang menyajikan peringkat 10 besar bank berdasarkan kategori jumlah aset tahun 2005-2008: 
Tabel 1

PERINGKAT 10 BESAR BANK BERDASARKAN

KATEGORI JUMLAH ASET

TAHUN 2005-2008

\begin{tabular}{|c|l|l|l|l|}
\hline No. & Tahun 2005 & Tahun 2006 & Tahun 2007 & Tahun 2008 \\
\hline 1 & Bank Mandiri & Bank Mandiri & Bank Mandiri & Bank Mandiri \\
\hline 2 & BCA & BCA & BCA & BRI \\
\hline 3 & BNI & BNI & BRI & BCA \\
\hline 4 & BRI & BRI & BNI & BNI \\
\hline 5 & Bank Danamon & Bank Danamon & Bank Niaga & Bank Danamon \\
\hline 6 & BII & BII & Bank Danamon & CIMB Niaga \\
\hline 7 & Bank Niaga & Bank Niaga & Bank PAN & Bank PAN \\
\hline 8 & Bank PAN & Bank PAN & BII & Bank Permata \\
\hline 9 & Bank Permata & Bank Permata & Citibank & BII \\
\hline 10 & Citibank & Citibank & Bank Permata & Citibank \\
\hline
\end{tabular}

Sumber: Direktori Perbankan Indonesia 2008 dan 2006

Metode analisis yang digunakan dalam penelitian ini adalah melakukan uji asumsi klasik dimana terdapat uji normalitas, autokorelasi, heteroskedatisitas dan multikolinieritas. Setelah melakukan uji asumsi, kemudian dilakukan uji pengaruh variabel bebas terhadap variabel terikat menggunakan analisis regresi linier berganda. Juga menghitung koefisien determinasi dari masing-masing variabel bebas. 


\section{ANALISIS DAN PEMBAHASAN}

Berikut adalah data-data mengenai nilai ROA (Return On Assets) dari 10 (sepuluh) bank dengan kategori aset terbesar di Indonesia selama tahun 2005-2008:

1. Tahun 2005

Tabel 2

NILAI ROA (RETURN ON ASSET) BANK PER DESEMBER 2005

(dalam persen)

\begin{tabular}{|c|l|c|}
\hline No. & \multicolumn{1}{|c|}{ Nama Bank } & ROA \\
\hline 1 & PT Bank Mandiri (Persero), Tbk & 3,19 \\
\hline 2 & PT Bank Rakyat Indonesia (Persero), Tbk & 5,04 \\
\hline 3 & PT Bank Central Asia, Tbk & 3,44 \\
\hline 4 & PT Bank Negara Indonesia, Tbk & 1,61 \\
\hline 5 & PT Bank Danamon Indonesia, Tbk & 4,26 \\
\hline 6 & PT Bank CIMB Niaga, Tbk & 2,10 \\
\hline 7 & PT PAN Indonesia Bank, Tbk & 2,27 \\
\hline 8 & PT Bank Permata, Tbk & 1,20 \\
\hline 9 & PT Bank Internasional IndonesiaTbk & 1,72 \\
\hline 10 & Citibank N.A. & 4,90 \\
\hline
\end{tabular}

Sumber: Direktori Perbankan Indonesia 2006

Dari tabel di atas dapat dilihat bahwa untuk tahun 2005, Bank Rakyat Indonesia memiliki nilai ROA (Return On Asset) tertinggi diantara bank lainnya dengan nilai ROA sebesar 5,04\%. Sedangkan Bank Permata memiliki nilai ROA (Return On Asset) terkecil diantara bank lainnya dengan nilai ROA sebesar 1,20\%. 
2. Tahun 2006

Tabel 3

NILAI ROA (RETURN ON ASSET) BANK

PER DESEMBER 2006

(dalam persen)

\begin{tabular}{|c|l|c|}
\hline No. & \multicolumn{1}{|c|}{ Nama Bank } & ROA \\
\hline 1 & PT Bank Mandiri (Persero), Tbk & 0,47 \\
\hline 2 & PT Bank Rakyat Indonesia (Persero), Tbk & 4,36 \\
\hline 3 & PT Bank Central Asia, Tbk & 3,80 \\
\hline 4 & PT Bank Negara Indonesia, Tbk & 1,85 \\
\hline 5 & PT Bank Danamon Indonesia, Tbk & 2,40 \\
\hline 6 & PT Bank CIMB Niaga, Tbk & 2,27 \\
\hline 7 & PT PAN Indonesia Bank, Tbk & 2,78 \\
\hline 8 & PT Bank Permata, Tbk & 1,20 \\
\hline 9 & PT Bank Internasional IndonesiaTbk & 1,43 \\
\hline 10 & Citibank N.A. & 4,53 \\
\hline
\end{tabular}

Sumber: Direktori Perbankan Indonesia 2006

Dari tabel di atas dapat dilihat bahwa untuk tahun 2006, Citibank memiliki nilai ROA (Return On Asset) tertinggi diantara bank lainnya dengan nilai ROA sebesar 4,53\%. Sedangkan Bank Mandiri memiliki nilai ROA (Return On Asset) terkecil diantara bank lainnya dengan nilai ROA sebesar $0,47 \%$. 
3. Tahun 2007

Tabel 4

NILAI ROA (RETURN ON ASSET) BANK

PER DESEMBER 2007

(dalam persen)

\begin{tabular}{|c|l|c|}
\hline No. & \multicolumn{1}{|c|}{ Nama Bank } & ROA \\
\hline 1 & PT Bank Mandiri (Persero), Tbk & 2,40 \\
\hline 2 & PT Bank Rakyat Indonesia (Persero), Tbk & 4,61 \\
\hline 3 & PT Bank Central Asia, Tbk & 3,34 \\
\hline 4 & PT Bank Negara Indonesia, Tbk & 0,85 \\
\hline 5 & PT Bank Danamon Indonesia, Tbk & 2,50 \\
\hline 6 & PT Bank CIMB Niaga, Tbk & 2,50 \\
\hline 7 & PT PAN Indonesia Bank, Tbk & 3,14 \\
\hline 8 & PT Bank Permata, Tbk & 1,90 \\
\hline 9 & PT Bank Internasional IndonesiaTbk & 1,43 \\
\hline 10 & Citibank N.A. & 5,68 \\
\hline
\end{tabular}

Sumber: Direktori Perbankan Indonesia 2008

Dari tabel di atas dapat dilihat bahwa untuk tahun 2007, Citibank memiliki nilai ROA (Return On Asset) tertinggi diantara bank lainnya dengan nilai ROA sebesar 5,68\%. Sedangkan Bank Negara Indonesia memiliki nilai ROA (Return On Asset) terkecil diantara bank lainnya dengan nilai ROA sebesar $0,85 \%$. 
4. Tahun 2008

\section{Tabel 5}

NILAI ROA (RETURN ON ASSET) BANK

PER DESEMBER 2008

(dalam persen)

\begin{tabular}{|c|l|c|}
\hline No. & \multicolumn{1}{|c|}{ Nama Bank } & ROA \\
\hline 1 & PT Bank Mandiri (Persero), Tbk & 2,69 \\
\hline 2 & PT Bank Rakyat Indonesia (Persero), Tbk & 4,18 \\
\hline 3 & PT Bank Central Asia, Tbk & 3,42 \\
\hline 4 & PT Bank Negara Indonesia, Tbk & 1,12 \\
\hline 5 & PT Bank Danamon Indonesia, Tbk & 1,58 \\
\hline 6 & PT Bank CIMB Niaga, Tbk & 1,10 \\
\hline 7 & PT PAN Indonesia Bank, Tbk & 1,75 \\
\hline 8 & PT Bank Permata, Tbk & 1,70 \\
\hline 9 & PT Bank Internasional IndonesiaTbk & 1,23 \\
\hline 10 & Citibank N.A. & 5,64 \\
\hline
\end{tabular}

Sumber: Direktori Perbankan Indonesia 2008

Dari tabel di atas dapat dilihat bahwa untuk tahun 2008, Citibank memiliki nilai ROA (Return On Asset) tertinggi diantara bank lainnya dengan nilai ROA sebesar 5,64\%. Sedangkan Bank CIMB Niaga memiliki nilai ROA (Return On Asset) terkecil diantara bank lainnya dengan nilai ROA sebesar $1,10 \%$.

Grafik di bawah ini adalah grafik nilai ROA dari 10 bank berdasarkan hasil pengolahan data: 


\section{Gambar 1}

\section{GRAFIK NILAI ROA DARI 10 BANK DENGAN KATEGORI}

ASET TERBESAR DI INDONESIA TAHUN 2005-2008

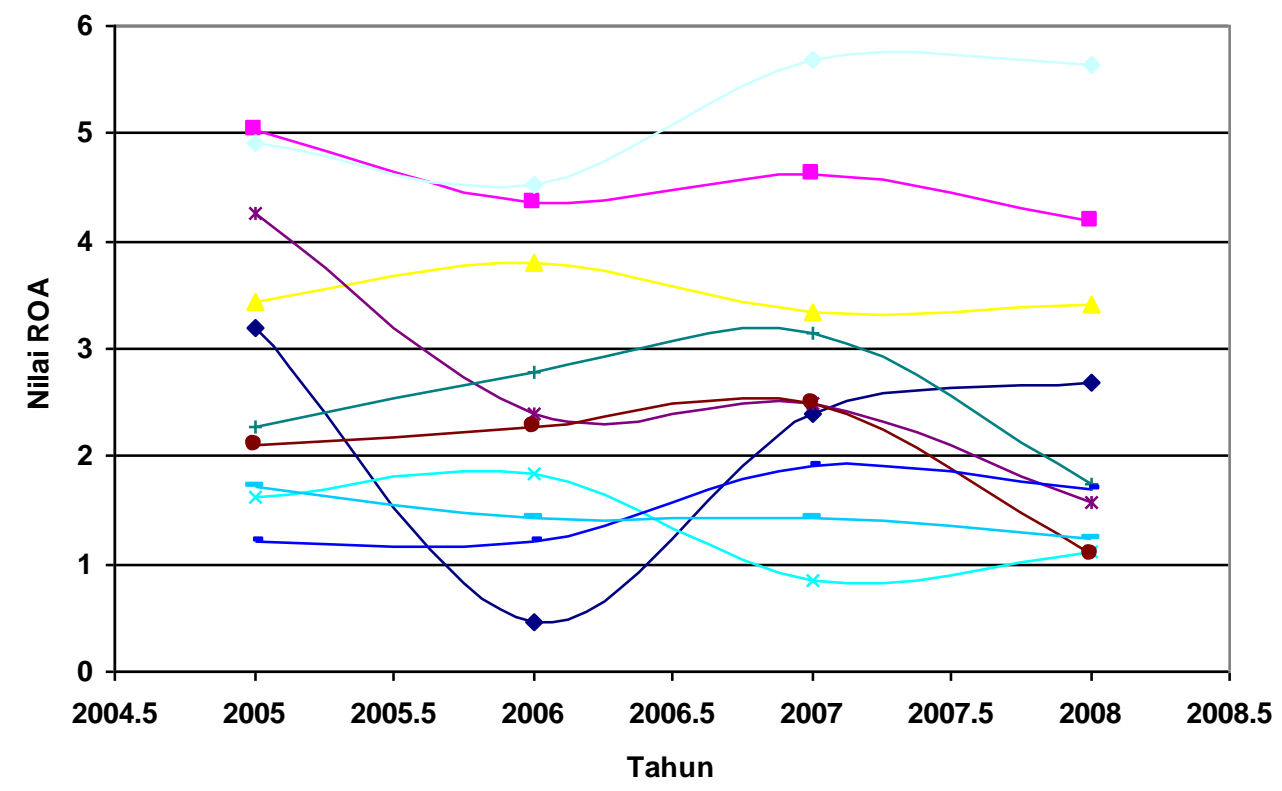

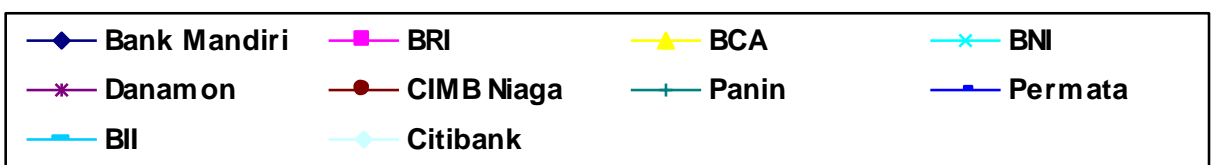

Sumber: Hasil Pengolahan Data Oleh Penulis

Grafik di atas menunjukkan bahwa dari tahun 2005-2008 terdapat beberapa bank yang memiliki nilai ROA yang cenderung stabil seperti Bank Rakyat Indonesia, Bank Central Asia, Bank Permata dan Bank Internasional Indonesia.

Berdasarkan data dari Badan Pusat Statistik Indonesia diperoleh data mengenai nilai GDP (Gross Domestic Product) Indonesia, sebagai berikut: 
Tabel 6

GDP (GROSS DOMESTIC PRODUCT) INDONESIA

TAHUN 2005-2008 (MILYAR RUPIAH)

\begin{tabular}{|c|c|c|}
\hline No. & Tahun & Jumlah \\
\hline 1 & 2005 & $2.774 .281,1$ \\
\hline 2 & 2006 & $3.339 .216,8$ \\
\hline 3 & 2007 & $3.949 .321,4$ \\
\hline 4 & 2008 & $4.954 .028,9$ \\
\hline
\end{tabular}

Sumber: $\underline{w w}$. bps.go.id

Data tingkat inflasi yang diperoleh dari Bank Indonesia adalah sebagai berikut:

Gambar 2

\section{GRAFIK TINGKAT INFLASI INDONESIA}

TAHUN 2005-2008

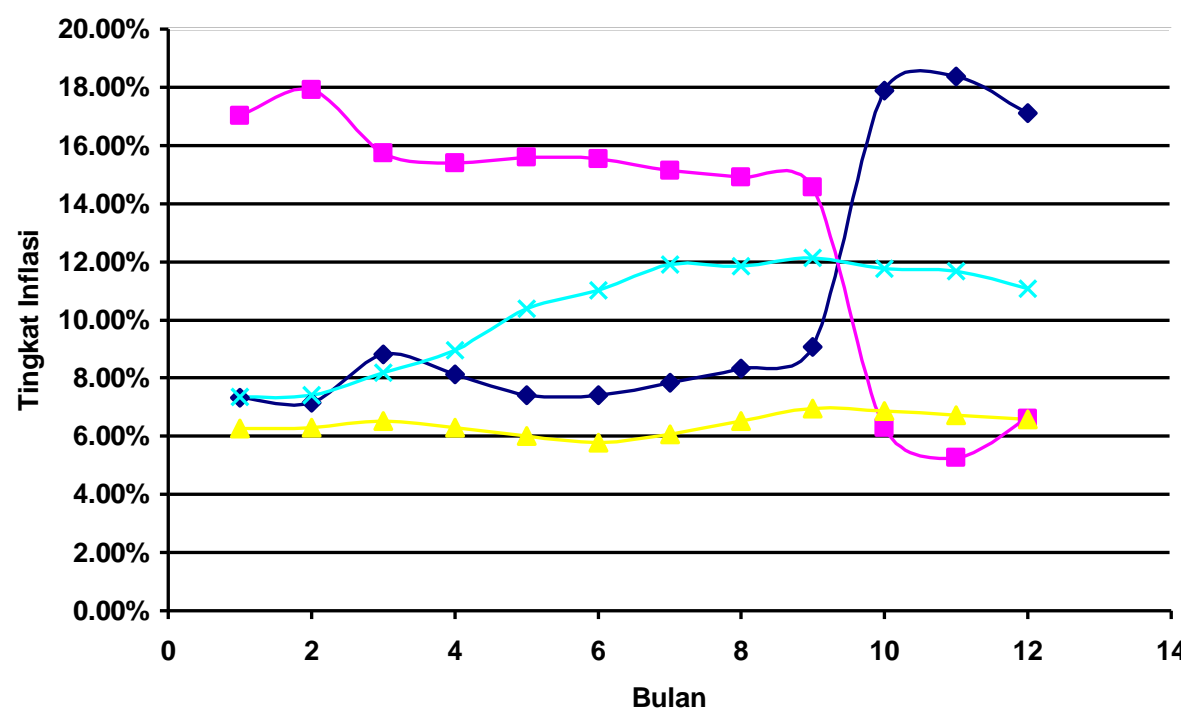

$$
\rightarrow-2005 \rightarrow-2006 \quad 2007 \quad \leftarrow 2008
$$

Sumber: www.bi.go.id 
Dari grafik di atas, dapat dilihat bahwa di tahun 2005, terjadi peningkatan inflasi yang cukup tajam mencapai hampir 9\% dari bulan September ke Oktober. Sedangkan di tahun 2006, pada bulan yang sama terjadi penurunan inflasi sebesar lebih dari 8\%. Pada tahun 2007 tingkat inflasi Indonesia relatif stabil berada pada lebih kurang 6\% untuk setiap bulannya. Di akhir tahun 2008 tingkat inflasi masih berada diatas $10 \%$.

\section{Uji Asumsi Klasik}

\section{Uji Normalitas Data}

\section{Normal P-P Plot of Regression Standardized Residual}

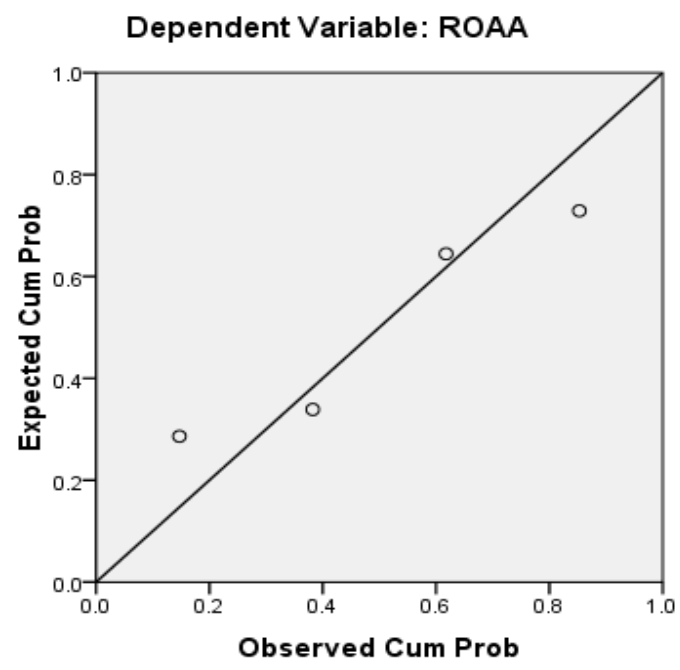

Hasil uji normalitas data menunjukkan bahwa data penelitian berdistribusi normal karena berada disekitar garis normal. 


\section{Autokorelasi}

\begin{tabular}{|l|r|r|r|r|r|}
\hline & & & Model Summary & \\
Model & $\mathrm{R}$ & R Square & \multicolumn{1}{c|}{$\begin{array}{c}\text { Squared R } \\
\text { Square }\end{array}$} & $\begin{array}{c}\text { Std. Error of the } \\
\text { Estimate }\end{array}$ & Durbin-Watson \\
\hline 1 & $.961^{\mathrm{a}}$ & .924 & .771 & .122240 & 2.018 \\
\hline
\end{tabular}
a. Predictors: (Constant), GDP, Inflasi
b. Dependent Variabel: ROAA

Nilai Durbin-Watson adalah sebesar 2,018. Nilai tersebut berada diantara 1,552,46 seperti yang terdapat dalam Tabel Klasifikasi Nilai d. Sehingga kita dapat menyimpulkan bahwa tidak terjadi autokorelasi diantara data pengamatan.

\section{Heteroskedatisitas}

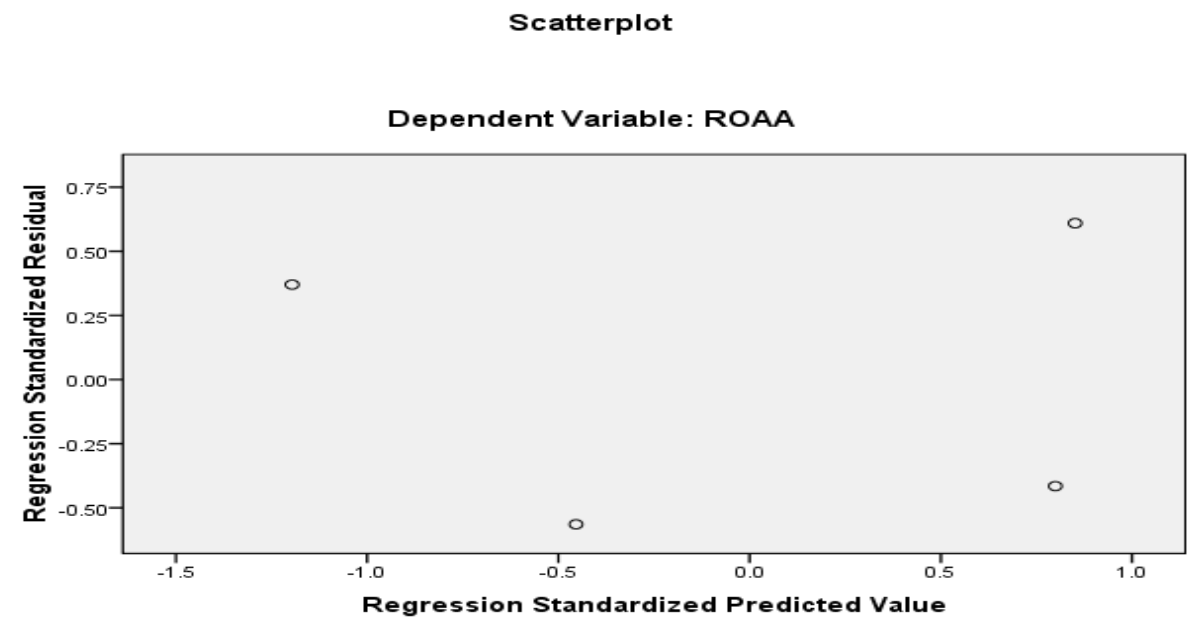

Kita dapat melihat data tidak membentuk suatu pola tertentu. Selain tidak membentuk pola tertentu, data juga menyebar baik diatas maupun dibawah angka 0 dari sumbu Y. Hal ini dapat kita simpulkan bahwa tidak terjadi heteroskedatisitas diantara data pengamatan. 


\section{Multikolinieritas}

\begin{tabular}{|c|c|c|c|c|c|c|c|}
\hline \multirow[b]{3}{*}{ Model } & \multicolumn{5}{|c|}{ Coefficients $^{\mathrm{a}}$} & & \\
\hline & \multicolumn{2}{|c|}{$\begin{array}{c}\text { Unstandardized } \\
\text { Coefficients }\end{array}$} & \multirow{2}{*}{\begin{tabular}{|c} 
Standardized \\
Coefficients
\end{tabular}} & \multirow[b]{2}{*}{$\mathrm{T}$} & \multirow[b]{2}{*}{ Sig. } & \multicolumn{2}{|c|}{ Collinearity Statistics } \\
\hline & B & Std. Error & & & & Tolerance & VIF \\
\hline 1 (Constant) & 4.214 & .443 & & 9.511 & .067 & & \\
\hline Inflasi & -.065 & .026 & -.721 & -2.526 & .240 & .935 & 1.069 \\
\hline GDP & $-2.313 \mathrm{E}-7$ & .000 & -.844 & -2.957 & .208 & .935 & 1.069 \\
\hline
\end{tabular}

a. Dependent Variabel:

ROAA

Nilai VIF untuk Inflasi dan GDP adalah 1,069. Nilai VIF ini jika dibandingkan dengan toleransi kolinearitas yang dianjurkan sebesar $<10$, maka dapat disimpulkan bahwa nilai VIF $<10$. sehingga dapat disimpulkan bahwa tidak terjadi heteroskedatisitas diantara data pengamatan.

\section{Uji pengaruh variabel bebas terhadap variabel terikat}

Perhitungan dilakukan untuk melihat apakah inflasi berpengaruh negatif dan signifikan terhadap ROAA jika GDP dikendalikan dan apakah GDP berpengaruh positif dan signifikan terhadap ROAA jika inflasi dikendalikan.

Pengujian dilakukan dengan melihat nilai $P$-value atau Significance pada Tabel Coefficients hasil analisis dengan software SPSS. Kita juga dapat membandingkan nilai t-hitung dengan t-tabel untuk melihat signifikan atau tidaknya pengaruh secara parsial variabel bebas terhadap variabel terikat.

Jika nilai P-value atau significance lebih kecil daripada alpha yang ditetapkan, maka dapat disimpulkan terdapat pengaruh yang signifikan variabel bebas terhadap variabel terikat. Jika nilai t-hitung lebih besar daripada t-tabel, maka dapat disimpulkan juga bahwa terdapat pengaruh yang signifikan variabel bebas terhadap variabel terikat. 


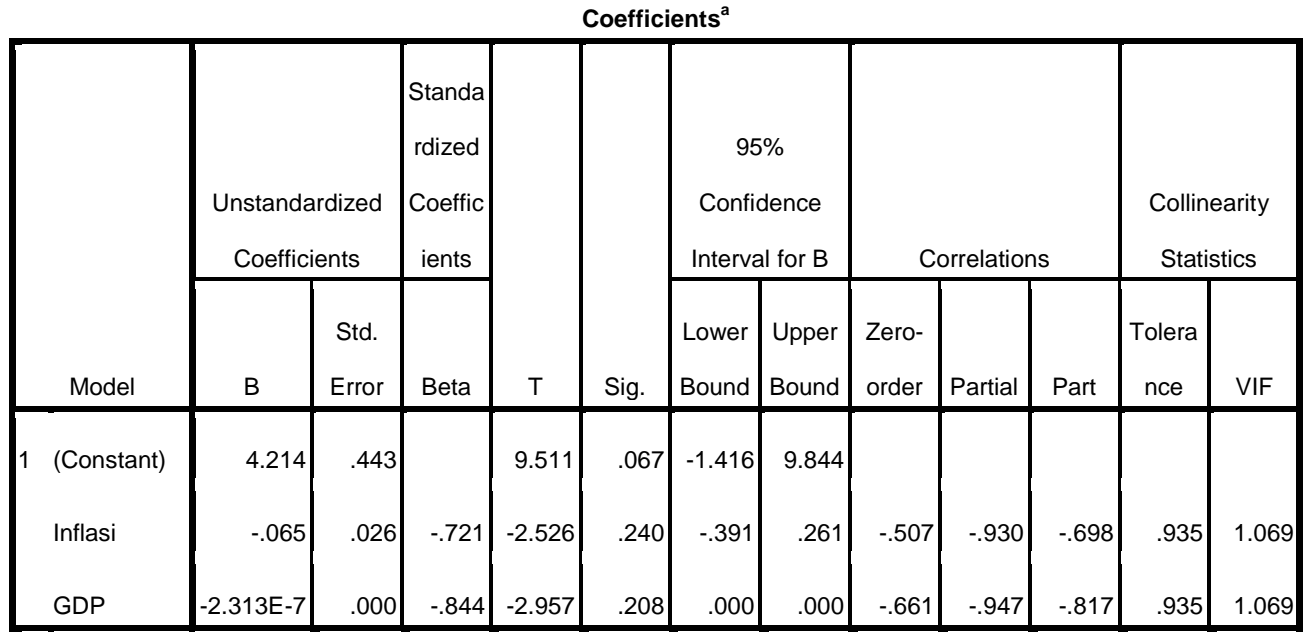

a. Dependent Variabel:

ROAA

Nilai $P$-value atau Significance untuk inflasi adalah sebesar 0,240 dan nilai $P$ value atau Significance untuk GDP adalah sebesar 0,208. Nilai P-value atau Significance ini dibandingkan dengan alpha yang telah ditetapkan.

Namun pada penelitian ini, pengujian dilakukan satu arah untuk inflasi dan GDP. Sehingga nilai $P$-value atau Significance harus dibagi 2. Nilai P-value atau Significance inflasi menjadi 0,120 dan nilai P-value atau Significance GDP menjadi 0,104 . Nilai $P$-value inflasi sebesar $0,120>$ alpha 0,05 dan nilai $P$-value GDP sebesar 0,104 > dari alpha 0,05.

Sehingga dapat kita simpulkan bahwa tidak terdapat pengaruh yang negatif dan signifikan inflasi terhadap ROAA jika GDP dianggap tetap atau dikendalikan. Dan tidak terdapat pengaruh yang positif dan signifikan GDP terhadap ROAA jika inflasi dianggap tetap atau dikendalikan.

\section{Koefisien determinasi}

Nilai koefisien korelasi parsial ROAA dan inflasi jika GDP dianggap tetap atau dikendalikan adalah sebesar -0,930. Sedangkan nilai koefisien korelasi parsial 
antara ROAA dan GDP jika inflasi dianggap tetap atau dikendalikan adalah sebesar -0,947. Untuk mencari nilai koefisien determinasi parsial maka nilai koefisien korelasi parsial yang diperoleh tersebut dikuadratkan.

Nilai koefisien determinasi $\left(\mathrm{R}^{2}\right)$ ROAA dan inflasi sebesar 0,8649. Artinya adalah variabel bebas $\mathrm{X}_{1}$ (Inflasi) mempengaruhi varians dari Y (ROAA) sebesar $86,49 \%$ jika GDP dianggap tetap atau dikendalikan. Sisanya sebesar 13,51\% dipengaruhi oleh variabel bebas lainnya.

Nilai koefisien determinasi $\left(\mathrm{R}^{2}\right)$ ROAA dan GDP sebesar 0,8968. Artinya adalah variabel bebas $\mathrm{X}_{2}$ (GDP) mempengaruhi varians dari Y (ROAA) sebesar 89,68\% jika inflasi dianggap tetap atau dikendalikan. Sisanya sebesar 10,32\% dipengaruhi oleh variabel bebas lainnya.

Namun, untuk hasil penelitian ini koefisien determinasi tidak dapat menerangkan kondisi sebenarnya karena hasil penelitian menunjukkan tidak ada pengaruh pengaruh variabel bebas terhadap variabel terikat.

\section{KESIMPULAN}

Berdasarkan hasil penelitian yang telah dilakukan dalam penelitian ini, maka penulis menyimpulkan hasil temuan dari penelitian sebagai berikut:

1. Tidak terdapat pengaruh yang signifikan inflasi terhadap ROAA (Return On Average Assets) jika GDP (Gross Domestic Product) dianggap tetap atau dikendalikan.

Hal ini dapat dilihat dari hasil penelitian yang menunjukkan bahwa nilai $P$ value atau Significance sebesar 0,120. Nilai P-Value atau Significance ini kemudian dibandingkan dengan nilai alpha yang telah ditetapkan yaitu sebesar 0,05 (5\%). Hasilnya menunjukkan bahwa nilai $P$-value atau Significance lebih besar daripada alpha yang ditetapkan.

Selain nilai $P$-value, dapat dilihat nilai t-hitung untuk inflasi sebesar -2,526 dan nilai t-tabel sebesar 2,920. Nilai t-hitung lebih kecil daripada nilai t-tabel. 
Sehingga disimpulkan bahwa tidak terdapat pengaruh yang signifikan inflasi terhadap ROAA (Return On Average Assets) jika GDP (Gross Domestic Product) dianggap tetap atau dikendalikan.

2. Tidak terdapat pengaruh yang signifikan GDP (Gross Domestic Product) terhadap ROAA (Return On Average Assets) jika inflasi dianggap tetap atau dikendalikan.

Hal ini dapat dilihat dari hasil penelitian yang menunjukkan bahwa nilai $P$ value atau Significance sebesar 0,104. Nilai P-Value atau Significance ini kemudian dibandingkan dengan nilai alpha yang telah ditetapkan yaitu sebesar 0,05 (5\%). Hasilnya menunjukkan bahwa nilai P-value atau Significance lebih besar daripada alpha yang ditetapkan.

Selain nilai $P$-value, dapat dilihat nilai t-hitung untuk GDP sebesar -2,957 dan nilai t-tabel sebesar 2,920. Nilai t-hitung lebih kecil daripada nilai t-tabel. Sehingga disimpulkan bahwa tidak terdapat pengaruh yang signifikan GDP (Gross Domestic Product) terhadap ROAA (Return On Average Assets) jika inflasi dianggap tetap atau dikendalikan.

Nilai koefisien determinasi untuk inflasi dan GDP adalah sebagai berikut:

1. Nilai koefisien determinasi $\left(\mathrm{R}^{2}\right)$ inflasi sebesar 0,8649. Artinya adalah variabel bebas $\mathrm{X}_{1}$ (Inflasi) mempengaruhi varians dari $\mathrm{Y}$ (ROAA) sebesar $86,49 \%$ jika $\mathrm{X}_{2}$ (GDP) dianggap tetap atau dikendalikan. Sisanya sebesar $13,51 \%$ dipengaruhi oleh variabel bebas lainnya.

2. Nilai koefisien determinasi $\left(\mathrm{R}^{2}\right)$ GDP sebesar 0,8968. Artinya adalah variabel bebas $\mathrm{X}_{2}$ (GDP) mempengaruhi varians dari Y (ROAA) sebesar 89,68\% jika $\mathrm{X}_{1}$ (inflasi) dianggap tetap atau dikendalikan. Sisanya sebesar 10,32\% dipengaruhi oleh variabel bebas lainnya. 


\section{DAFTAR PUSTAKA}

Arnold, Roger A., 2008, Economics, Eighth Edition, Thomson South-Western, USA.

Kuncoro, Mudrajad., 2003, Metode Riset untuk Bisnis dan Ekonomi, Erlangga, Jakarta.

Kosmidou, Kyriaki., 2008, The Determinants of Banks' Profits in Greece during The Period of EU Financial Integration, Vol.34, p146, Patrington.

McConnell, Campbell dan Brue, Stanley L, 2008, Economics, Seventeenth Edition, McGraw-Hill Companies Inc., Singapore.

McEachern, William A, 2003, Economics, $6^{\text {th }}$ Edition, Thomson South-Western, USA.

Narbuko, Cholid dan Achmadi, Abu., 2008, Metodologi Penelitian, Bumi Aksara, Jakarta.

Parkin, Michael., 2008, Economics, $8^{\text {th }}$ Edition, Pearson Education Inc., USA.

Siamat, Dahlan., 2005, Manajemen Lembaga Keuangan, Edisi Kelima, Fakultas Ekonomi Universitas Indonesia, Jakarta.

Sugiyono, 2009, Metode Peneltian Bisnis, Alfabeta, Bandung.

Supranto, J., 2009, Statistik: Teori dan Aplikasi, Edisi Ketujuh, Jilid 2, Erlangga, Jakarta.

Uyanto, Stanislaus S., 2009, Pedoman Analisis Data dengan SPSS, Graha Ilmu, Yogyakarta.

Wijaya, Tony., 2009, Analisis Data Penelitian Menggunakan SPSS, Universitas Atma Jaya Yogyakarta, Yogyakarta.

Williamsom, Stephen D., 2008, Macroeconomics, Third Edition, Pearson Education Inc., USA. 